\title{
Erzurum İli Hınıs İlçesi Sığırcılık İşletmelerinin Barınak Özellikleri Üzerine Bir Araştırma
}

\author{
Recep AYDIN ${ }^{1}$, Olcay GÜLER ${ }^{2}$, Mete YANAR ${ }^{1}$, Abdulkerim DILER ${ }^{2}$, \\ Rıdvan KOÇYİĞíT ${ }^{1}$, Mehmet AVCI ${ }^{1}$ \\ ${ }^{1}$ Atatürk Üniversitesi, Ziraat Fakültesi, Zootekni Bölümü, Erzurum \\ ${ }^{2}$ Atatürk Üniversitesi, Hınıs Meslek Yüksekokulu Laborant ve Veteriner Sağlığı Bölümü, Erzurum
}

Geliş (Received): 29.01.2016

Kabul (Accepted): 25.03.2016

\begin{abstract}
ÖZET: $\mathrm{Bu}$ araştırma, Erzurum ili Hınıs ilçesinde faaliyet gösteren sı̆̆ırcılık işletmelerinin barınak özellikleri hakkında ayrıntılı bilgi edinmek üzere yürütülmüştür. Bu amaçla, 378 adet sığırcılık işletme sahibi ile yüz yüze anket yapılarak elde edilen veriler değerlendirilmiştir. Değişkenler arasındaki ilişkilerin belirlenmesi amacıyla da kikare testi yapılmıştır. Hınıs ilçesinde en sık görülen ahır tipinin bağlı duraksız kapalı ahır (\% 51.5) olduğu, ahır yapısının işletme sahiplerinin sağlıklarını (\% 88.8), ineklerin süt verimini (\% 88.6) ve hayvanların gelişimini (\% 81.0) olumsuz etkilediği tespit edilmiştir. İşletmelerin \% 81.0'i yataklık kullanmazken, yataklık kullananların ise daha çok kuru gübre kullanımını (\% 63.3) tercih etmişlerdir. İşletmelerin \% 61.3'ünde buzağılara ait özel bir bölme bulunduğu, ahırların \% 74.9'unda inekler için doğum bölmesi olmadığı; düve, dana ve kurudaki ineklerin birlikte (\% 84.3) barındırıldıkları belirlenmiştir. İşletmelerin \% 84.1'inde ahırdaki gübre elle süpürme yoluyla temizlenmekte, gübreyi çok büyük oranda ahır yakınında açıkta (\% 80.3) depolamaktadırlar. İşletmelerin \% 69.9'u gübreyi tarlada gübre olarak, \% 13.4' ünün yakacak olarak kullandığ 1 , \% 11.8'inin ise sattığı tespit edilmiştir. İşletmelerin \% 72.1 'i kışın ahır içi sıcaklığının ılık, \% 27.3'ü ise sıcak olduğunu, \% 84.0’ü ahır içi sıcaklığının ılık olması halinde hayvanların rahat ettiği ve süt verimlerinin yükseldiğini belirtmişlerdir. Sonuç olarak Hınıs ilçesinde barınak ve çevre yapısı özellikleri bakımından birçok eksikliklerinin bulunduğu ve ahır tipi, yapısı, havalandırma, aydınlatma, yataklık kullanımı, gübre değerlendirme vb. konularda iyileştirme çalışmalarına ihtiyacı olduğu ortaya konulmuştur. Anahtar Kelimeler: Ahır tipi, yataklık, havalandırma, aydınlatma, gübre değerlendirme
\end{abstract}

\section{A Study on the Characteristics of the Barns in Hınıs County of Erzurum Province}

ABSTRACT: The study was carried out to obtain detailed information about characteristics of barns in the cattle farm enterprises in Hinıs County of Erzurum Province. For this purpose, data obtained from a survey that was conducted face to face with 378 of owners of the enterprises were assessed. Chi-square Test was used in order to determine relationships among the variables. It was revealed that the most common type of the barns was tied-free stall barns (\% 51.5), and types of the barn affected adversely on the health of the owners of the enterprises (\% 88.8), on the milk yield of the cows $(\%$ 88.6) as well as on the growth of the animals $(\%$ 81.0). While 81.0 of the enterprises did not use bedding material, $63.3 \%$ of the enterprises which were using bedding material preferred commonly to use dried manure. Besides, It was found out that $61.3 \%$ of the enterprises had special compartment for calves, but $74.9 \%$ of the barns did not contain delivery chamber, and heifers, older calves as well as dry cows were housed together $(\% 84.3)$. In $84.1 \%$ of the enterprises, manure in the barn was cleaned by sweeping with a broom, and then the manure was generally stored next to the barn without covering. It was also revealed that $69.9 \%$ of the enterprises used the manure in their fields as fertilizer, and $13.4 \%$ of them utilized as fuel for heating, and $11.8 \%$ of the enterprise sold to others. $72.1 \%$ and $27.3 \%$ of the enterprises had warm and hot barns respectively, and $84.0 \%$ of the owners of the enterprises told that if their barns are warm, their animals will feel comfortable and their milk yield will increase. In conclusion, there are several deficiencies concerning features of the barns and their environments in Hinis County, and the county needs improvements in terms of types of barn , barn ventilation, lighting, usage of bedding and manure subjects.

Key Words: Type of barn, bedding material, ventilation, lighting and usage of manure

\section{GİRIŞ}

Hayvan başına üretimin artırılması; yüksek verimli, genotipik değeri üstün bireylerin sayılarının artırılması, hayvanların daha iyi beslenmesi, hastalık ve zararlılarla daha iyi mücadele edilmesi ve hayvanların rahat edebildikleri uygun çevre koşullarına sahip barınaklarda barındırılmasıyla sağlanabilir. Hayvanların sağlık ve verimlerinin, genellikle barınak içi çevre koşulları ile sıkı bir ilişkisi vardır. $\mathrm{Bu}$ nedenle, hayvanlardan maksimum verim alınabilmesi için, barınakların yapısal özellikleri ile teknik donanımlarının optimum düzeyde olması çok önemlidir. Erzurum ilinde hayvancılık, temel geçim kaynaklarının başında gelmekte, il genelinde mera alanlarının yaygın olarak bulunması ve mevcut iklim koşulları tarımın diğer kollarına nazaran hayvancılığın daha çok gelişmesinde etkili olmuştur (Okuroğlu ve Delibaş, 1986).

TÜİK verilerine göre, Erzurum ilinde 686183 baş sığır yetiştirilmektedir (TUIK, 2015). Büyükbaş hayvan varlığı açısından Hınıs ilçesi 39011 baş hayvana sahip 
olup bu değer Erzurum ili sığır varlığının \% 5.86'sın teşkil etmektedir. İlçe, coğrafik ve iklimsel özellikler açısından il merkezine göre farklılıklar göstermektedir. İlçede hayvansal üretim, bitkisel üretime göre daha fazla ekonomik önem arz etmektedir. Hayvansal üretimin artırılması ve hayvan refahı açısından dünyada (Dou ve ark., 2001; Vasseur ve ark., 2010; Sheppard ve ark., 2011) ve Türkiye'de (Han ve Bakır, 2010; Şeker ve ark., 2012; Tilki ve ark., 2013; Daş ve ark., 2014; Özyürek ve ark., 2014) değişik yörelerde mevcut hayvan barınaklarına ait yapı özelliklerinin incelendiği çalışmaların son yıllarda oldukça fazla yoğunlaştığı görülmektedir. Ancak konu ile ilgili Erzurum ili Hınıs İlçesinde yürütülen detaylı bir çalışma mevcut değildir. $\mathrm{Bu}$ nedenle, araştırma Erzurum ili Hınıs ilçesinde mevcut sığır barınaklarının yapısal özelliklerinin incelenerek mevcut durum ve sorunları ortaya koymak amaciyla düzenlenmiştir.

\section{MATERYAL ve METOT}

Araştırma materyalini, Hınıs ilçe merkezi ve köylerinde bulunan sı̆̆ırcılık işletmelerinden elde edilen veriler oluşturmuştur. Hınıs Tarım İlçe Müdürlüğü kayıtlarından alınan toplam işletme sayısı dikkate alınarak 5190 işletmeden $378^{\prime}$ 'inde işletme sahibi ile yüz yüze görüşülerek anket çalışması gerçekleştirilmiştir.

Anket sayısının belirlenmesi ise Oransal Örnekleme Yöntemi ile yapılmıştır. Yöntemde \% 95 güven aralığı, $\% 5$ hata payı ile aşağıdaki formül kullanılmıştır (Newbold, 1995).

$$
\mathrm{n}=\frac{\mathrm{N}^{*} \mathrm{p} *(1-\mathrm{p})}{(\mathrm{N}-1) * \sigma_{\mathrm{p}}^{2}+\mathrm{p} *(1-\mathrm{p})}
$$

Formülde;

$\mathrm{n}$ : Örnek büyüklüğü,

$\mathrm{N}$ : Üretici sayıs1,

$\sigma_{\mathrm{p}}^{2}$ : Oranın varyansı,

$\mathrm{Z}_{\alpha / 2}: \mathrm{Z}$ cetvel değeri

$\mathrm{p}$ : İşletme sayısının popülasyondaki oranını göstermektedir.

$$
\begin{aligned}
& \sigma_{p}{ }^{2}=\frac{0.05}{1.96}=0.0255 \\
& n=\frac{5190 * 0.5 * 0.5}{\left(5189 * 0.0255^{2}\right)+(0.5 * 0.5)}=357.95
\end{aligned}
$$

Araştırmada maksimum örnek hacmine ulaşılmak istenmiştir. $\mathrm{Bu}$ amaçla $\mathrm{p}=0.0$ ve $(1-\mathrm{p})=0.50$ alınmıştır. Bu tür hesaplamalarda örnek hacminin en az \% 3.0 (Yamane, 2006) veya \% 10'un alınması yeterli olacağı (Cochran, 1977), ancak örnek hacminin birim sayısı arttıkça ana kitleyi daha iyi temsil etme yeteneğini de yükselteceği bildirilmektedir (Sümbüloğlu ve Sümbüloğlu, 1998). Araştırmada anket sayısı \% 5.0
(20 adet) artırılarak Hınıs ilçesinde toplam 378 yetiştirici ile anket yapılmıştır.

Elde edilen veriler işletmenin yapısal durumunu etkileyen işletme ölçek büyüklüğü [5 grup (1-10, 11-20, $21-30,31-40$ ve $41+$ baş)], eğitim durumu [6 grup (Okuryazar değil, ilkokul terk, ilkokul mezunu, ortaokul mezunu, lise mezunu, üniversite mezunu), deneyim (yıl) [4 grup (0-10, 11-20, 21-30, 30+ y1l) dikkate alınarak SPSS paket programında analiz edilmiştir (SPSS, 2004). Değişkenler arasındaki ilişkilerin belirlenmesinde kikare testi uygulanmıştır (Yıldız ve Bircan, 2006). Bazı özellikleri incelerken " $n$ " sayısının farklı olmasının nedeni yetiştiricilerin anketteki bazı sorulara cevap vermemiş olmasından kaynaklanmaktadır.

\section{BULGULAR ve TARTIŞMA}

\section{Ahırların Yapısal Özellikleri}

Hınıs ilçesinde bulunan ahır tipleri arasında en yaygın olanını \% 51.5 oranıyla bağlı duraksız kapalı ahırlar teşkil etmektedir (Çizelge 1). Bu tip ahırları, sırasıyla serbest duraklı kapalı ahırlar (\% 23.1), bağlı duraklı kapalı ahırlar (\% 15.7), serbest duraksız kapalı ahırlar (\% 5.8), açık ahırlar (\% 2.2) ve yarı açık ahırlar (\% 1.7) takip etmiştir. Alışkanlıklarla beraber, ahırların nispeten küçük, iç tasarımının hayvanların serbest bir şekilde dolaşımı, yemlenmesi, sağımı vb. işleri gerçekleştirilmesine olanak sağlamaması gibi nedenler, söz konusu ahırların bağlı olmasını zorunlu kılmış olabilir. Ayrıca, işletmelerde yemliklerin duvara bitişik bir pozisyonda olmas1, yemlik yolunun bulunmaması, özellikle yemleme ve sağım sırasında bakıcıların hayvanların aralarına girebilmeleri için duraksız sistemin daha çok tercih edildiği düşünülebilir.

Türkiye'de yürütülen diğer çalışmalarda da, bağlı duraksız kapalı ahırların yaygınlığ 1 Kayseri ilinde \% 75.0 (Uğurlu ve Şahin, 2010), Kahramanmaraş’ta \% 97.0 (Kaygısız ve Tümer, 2009), Muş ilinde \% 97.5 (Şeker ve ark., 2012) ve Ağrı ilinde de \% 97.2 (Bakan, 2014) olarak bildirilmiştir. Öte yandan, Kars ilinde (Tilki ve ark, 2013) işletmelerin \% 79.1'inin kapalı ahırlardan, Güney Doğu Anadolu Bölgesi'ndeki işletmelerde ise ahırların \% 17.5'inin kapalı ahırlardan, $\%$ 82.5'inin ise yarı açık ahır ahırlardan oluştuğu rapor edilmiştir (Yener ve ark., 2013). Dou ve ark. (2001) ise Pennsylvania eyaletindeki sığır işletmelerinin \% 35.0'inin serbest duraklı ahırlardan, \% 68.0'inin bağlı duraklı ahırlardan oluştuğunu tespit etmişlerdir. $\mathrm{Bu}$ araştırmalardan elde edilen sonuçlara göre, iklim faktörü ve coğrafik koşullarla beraber işletme sahiplerinin eğitim düzeyi, ekonomik gücü, eğitim programlarının uygulanma durumu vb. dünyanın farklı yörelerindeki barınak tiplerinin belirlenmesinde etkili faktörler arasında olduğu söylenebilir.

Hınıs ilçesindeki 1-40 baş arası hayvana sahip işletmelerde bağlı duraksız kapalı ahırların daha fazla oranda tercih edildiği, işletme ölçeği büyüdükçe serbest duraklı kapalı ahır oranlarının \% 5.0'ten \% 60.0'a doğru bir artış gösterdiği tespit edilmiştir (Şekil 1). Bağlı duraklı kapalı ahır oranlarının ise, işletmedeki hayvan 
sayısı artışına paralel olarak azaldığı görülmüştür. İşletme ölçeği ile ahır tipleri arasındaki ilişkinin önemli $(\mathrm{P}<0.01)$ olduğu belirlenmiştir (Çizelge 1).

Ankete katılan işletmelerin \% 3.4'ü ahırlarını 5 yıldır kullandıklarını bildirirken, \% 16.2'si 6-10 y11, \% 51.8'i 11-15 yıl, \% 17.4'ü 16-20 yıl, \% 11.2'si de 21 yıldan daha uzun sürelerde barınaklarından istifade ettiklerini belirtmişlerdir (Çizelge 2). Hınıs ilçesinde yeni olarak nitelendirebilecek (0-10 yıllık) ahırların oranı \% 19.6 dır. Isşletmelerin \% 51.8'inin ahırları 11-15 yıllık olup, ilçedeki toplam hayvan barınaklarının \% 80.4'ü 11 yıldan daha eski olduğu saptanmıştır.
Ağrı ilindeki işletmelerin ortalama barınak yaşı (13.0 \pm 0.7 yıl) ile (Bakan, 2014) kıyaslandığında Hınıs ilçesindeki 11-15 yıl değerleri arasında yer alması ile benzerlik göstermektedir. Kars ilinde yapılan bir çalışmada bildirilen ortalama barınak yaşının (18.2 yıl) Hınıs ilçesinde bulunan ahırlardan daha yüksek olduğu görülmüştür (Tilki ve ark., 2013). Ahırı kullanma süresi ahırın yeni ya da eski olma durumu ile ilgili bilgi vermekte olup elde edilen değerler ahırın kullanım süresinin normal değerler arasında olduğunu göstermektedir.

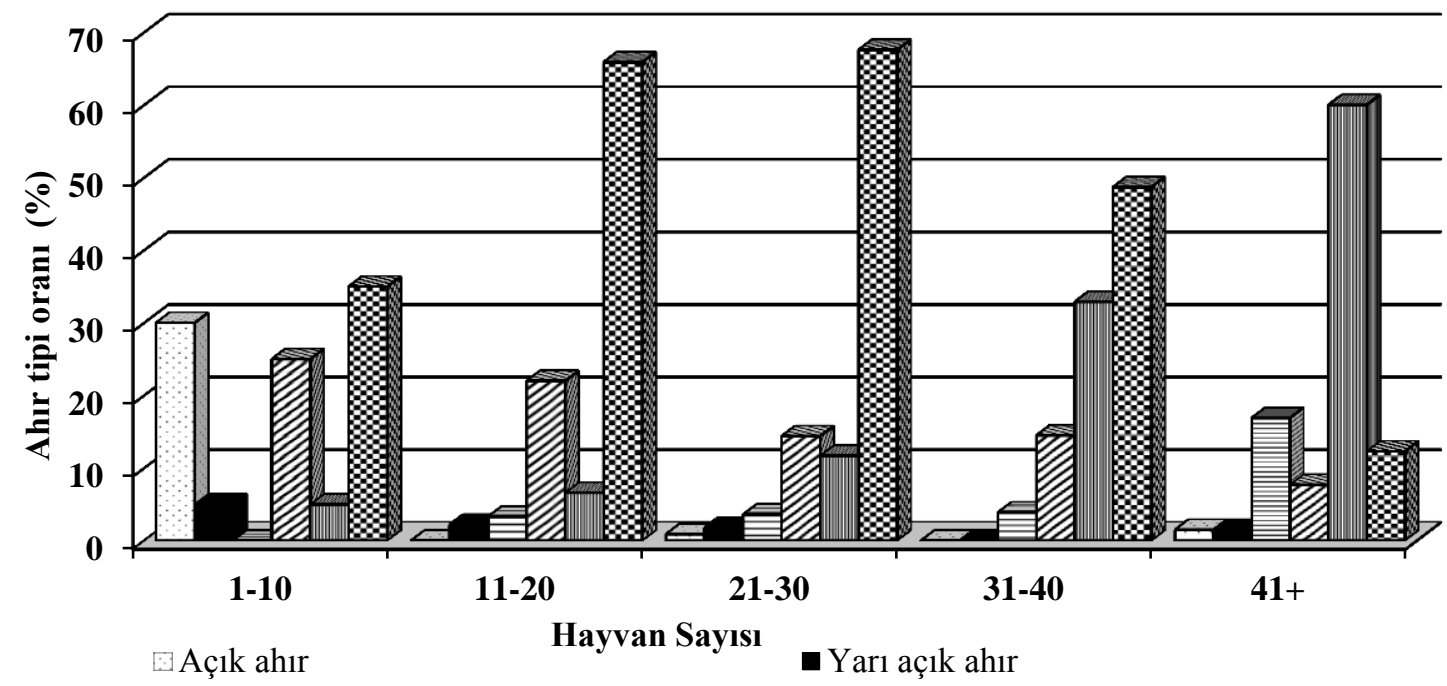

$\boxminus$ Serbest duraksız kapalı ahır

m Serbest duraklı kapalı ahır \ağlı duraklı kapalı ahır

- Bağlı duraksız kapalı ahır

Şekil 1. Hayvan sayısına göre ahır tiplerindeki değişim

Çizelge 1. Hayvan sayısı sınıfları ve ahır tipleri

\begin{tabular}{|c|c|c|c|c|c|c|c|c|c|c|c|c|}
\hline \multirow[b]{3}{*}{ Ahır tipleri } & \multicolumn{10}{|c|}{ Hayvan sayısı } & & \\
\hline & \multicolumn{2}{|c|}{$1-10$ baş } & \multicolumn{2}{|c|}{$11-20$ baş } & \multicolumn{2}{|c|}{$21-30$ baş } & \multicolumn{2}{|c|}{$31-40$ baş } & \multicolumn{2}{|c|}{$41+$ baş } & \multicolumn{2}{|c|}{ Toplam } \\
\hline & Adet & $\%$ & Adet & $\%$ & Adet & $\%$ & Adet & $\%$ & Adet & $\%$ & Adet & $\%$ \\
\hline Açık ahır & 6 & 30.0 & 0 & 0.0 & 1 & 0.9 & 0 & 0.0 & 1 & 1.5 & 8 & 2.2 \\
\hline Yarı açık ahır & 1 & 5.0 & 2 & 2.2 & 2 & 1.8 & 0 & 0.0 & 1 & 1.5 & 6 & 1.7 \\
\hline Bağlı duraklı kapalı ahır & 5 & 25.0 & 20 & 22.0 & 16 & 14.4 & 11 & 14.5 & 5 & 7.7 & 57 & 15.7 \\
\hline Serbest duraklı kapalı ahır & 1 & 5.0 & 6 & 6.6 & 13 & 11.7 & 25 & 32.9 & 39 & 60.0 & 84 & 23.1 \\
\hline Bağlı duraksız kapalı ahır & 7 & 35.0 & 60 & 65.9 & 75 & 67.6 & 37 & 48.7 & 8 & 12.3 & 187 & 51.5 \\
\hline Serbest duraksız kapalı ahır & 0 & 0.0 & 3 & 3.3 & 4 & 3.6 & 3 & 3.9 & 11 & 16.9 & 21 & 5.8 \\
\hline Toplam & 20 & 100 & 91 & 100 & 111 & 100 & 76 & 100 & 65 & 100 & 363 & 100 \\
\hline \multicolumn{13}{|c|}{$X^{2}=192.196$} \\
\hline
\end{tabular}


Çizelge 2. Ahırı kullanım süresi (yıl)

\begin{tabular}{ccc}
\hline Kullanım & Adet & \% \\
Süresi (yıl) & 12 & 3.4 \\
$0-5$ & 58 & 16.2 \\
$6-10$ & 185 & 51.8 \\
$11-15$ & 62 & 17.4 \\
$16-20$ & 40 & 11.2 \\
$21+$ & $\mathbf{3 5 7}$ & $\mathbf{1 0 0}$ \\
\hline Toplam & & \\
\hline
\end{tabular}

Hınıs ilçesindeki sığırcılık işletmelerinin \% 70.7'sinde ahırların müstakil olduğu, \% 30.3'ünde ise ev altında bulunduğu tespit edilmiştir (Çizelge 3).

Müstakil ahırlara ait oranın benzer şekilde Muş ilinde \% 77 (Şeker ve ark., 2012), Kahramanmaraş ilinde \% 63 (Kaygısız ve Tümer, 2009) ve Diyarbakır'da ise (Han ve Bakır, 2010) büyük çoğunluğu müstakil olarak bildirilmiştir. Bu bulguların aksine Karadeniz bölgesinde Giresun ilinde ise ev altı barınak oranının daha yüksek olduğu $\left(\begin{array}{ll}\% & 62.2\end{array}\right)$ bildirilmiștir (Tugay ve Bakır, 2006). Doğu Anadolu ve Karadeniz Bölgelerinin topoğrafik yapılarındaki farkların ve işletme başına kullanılabilir arazi miktarlarının farklı olmasının ahır konumunun seçiminde etkili bir faktör olabileceği söylenebilir.

İșletme ölçeğine göre ahırın konumu; incelendiğinde işletmede hayvan sayısı arttıkça müstakil ahır oranının tedricen azaldığı, ev altı ahır oranının ise tedricen artış gösterdiği ve müstakil ahır oranını geçtiği görülmektedir (Şekil 2).

Eğitim durumuna göre müstakil ahır oranı üniversite mezunlarında en yüksek (\% 100.0), lise mezunlarında ise en düşük düzeyde (\% 33.3) gerçekleşmiştir (Çizelge 4).

Ev altı ahır oranı ise en çok lise mezunu (\% 66.7) işletmecilerde görülmektedir. Üniversite mezunu işletmecilerde ise Ev altı ahır görülmemektedir (Şekil $3)$.

Deneyim durumuna göre ahır konumu incelendiğinde ise deneyim süresi 10 yıla kadar olanlarda müstakil ahır oranı $\% 88.9$ iken $30+$ y1l deneyime sahip olanlarda tedricen azalarak \% 56.5 düzeyine düşmüştür. Ev altı ahır oranı ise \% 11.1 den $\%$ 43.3'e yükselmiştir (Çizelge 5).

Çizelge 3. Hayvan sayısı ve ahır konumu

\begin{tabular}{|c|c|c|c|c|c|c|c|c|c|c|c|c|}
\hline \multirow[b]{3}{*}{ Ahır Konumu } & \multicolumn{10}{|c|}{ Hayvan sayısı } & & \\
\hline & \multicolumn{2}{|c|}{$1-10$ baş } & \multicolumn{2}{|c|}{$11-20$ baş } & \multicolumn{2}{|c|}{$21-30$ baş } & \multicolumn{2}{|c|}{ 31-40 baş } & \multicolumn{2}{|c|}{$41+$ baş } & \multicolumn{2}{|c|}{ Toplam } \\
\hline & Adet & $\%$ & Adet & $\%$ & Adet & $\%$ & Adet & $\%$ & Adet & $\%$ & Adet & $\%$ \\
\hline Müstakil & 15 & 83.3 & 70 & 92.1 & 60 & 67.4 & 35 & 60.3 & 15 & 42.9 & 195 & 70.7 \\
\hline Ev altı & 3 & 16.7 & 6 & 7.9 & 29 & 32.6 & 23 & 39.7 & 20 & 57.1 & 81 & 29.3 \\
\hline \multirow[t]{2}{*}{ Toplam } & 18 & 100 & 76 & 100 & 89 & 100 & 58 & 100 & 35 & 100 & 276 & 100 \\
\hline & & & & $X^{2}=$ & & $P=0.0$ & & & & & & \\
\hline
\end{tabular}

$* * \mathrm{P}<0.01$

Çizelge 4. Eğitim durumu ve ahır konumu

\begin{tabular}{|c|c|c|c|c|c|c|c|c|c|c|c|c|c|c|}
\hline \multirow[b]{3}{*}{ Ahır Konumu } & \multicolumn{12}{|c|}{ Eğitim durumu } & & \\
\hline & \multicolumn{2}{|c|}{$\begin{array}{l}\text { Okuryazar } \\
\text { değil }\end{array}$} & \multicolumn{2}{|c|}{$\begin{array}{l}\text { İlkokul } \\
\text { terk }\end{array}$} & \multicolumn{2}{|c|}{$\begin{array}{l}\text { İlkokul } \\
\text { mezunu }\end{array}$} & \multicolumn{2}{|c|}{$\begin{array}{l}\text { Ortaokul } \\
\text { mezunu }\end{array}$} & \multicolumn{2}{|c|}{$\begin{array}{l}\text { Lise } \\
\text { mezunu }\end{array}$} & \multicolumn{2}{|c|}{$\begin{array}{l}\text { Üniversite } \\
\text { mezunu }\end{array}$} & \multicolumn{2}{|c|}{ Toplam } \\
\hline & Adet & $\%$ & Adet & $\%$ & Adet & $\%$ & Adet & $\%$ & Adet & $\%$ & Adet & $\%$ & Adet & $\%$ \\
\hline Müstakil & 6 & 85.7 & 137 & 66.2 & 37 & 97.4 & 7 & 77.8 & 3 & 33.3 & 5 & 100.0 & 195 & 70.9 \\
\hline Ev altı & 1 & 14.3 & 70 & 33.8 & 1 & 2.6 & 2 & 22.2 & 6 & 66.7 & 0 & 0.0 & 80 & 29.1 \\
\hline \multirow[t]{2}{*}{ Toplam } & 7 & 100 & 207 & 100 & 38 & 100 & 9 & 100 & 9 & 100 & 5 & 100 & 275 & 100 \\
\hline & & & & \multicolumn{2}{|c|}{$X^{2}=27.299$} & & $P=0.00$ & & & & & & & \\
\hline
\end{tabular}

$* * \mathrm{P}<0.01$ 


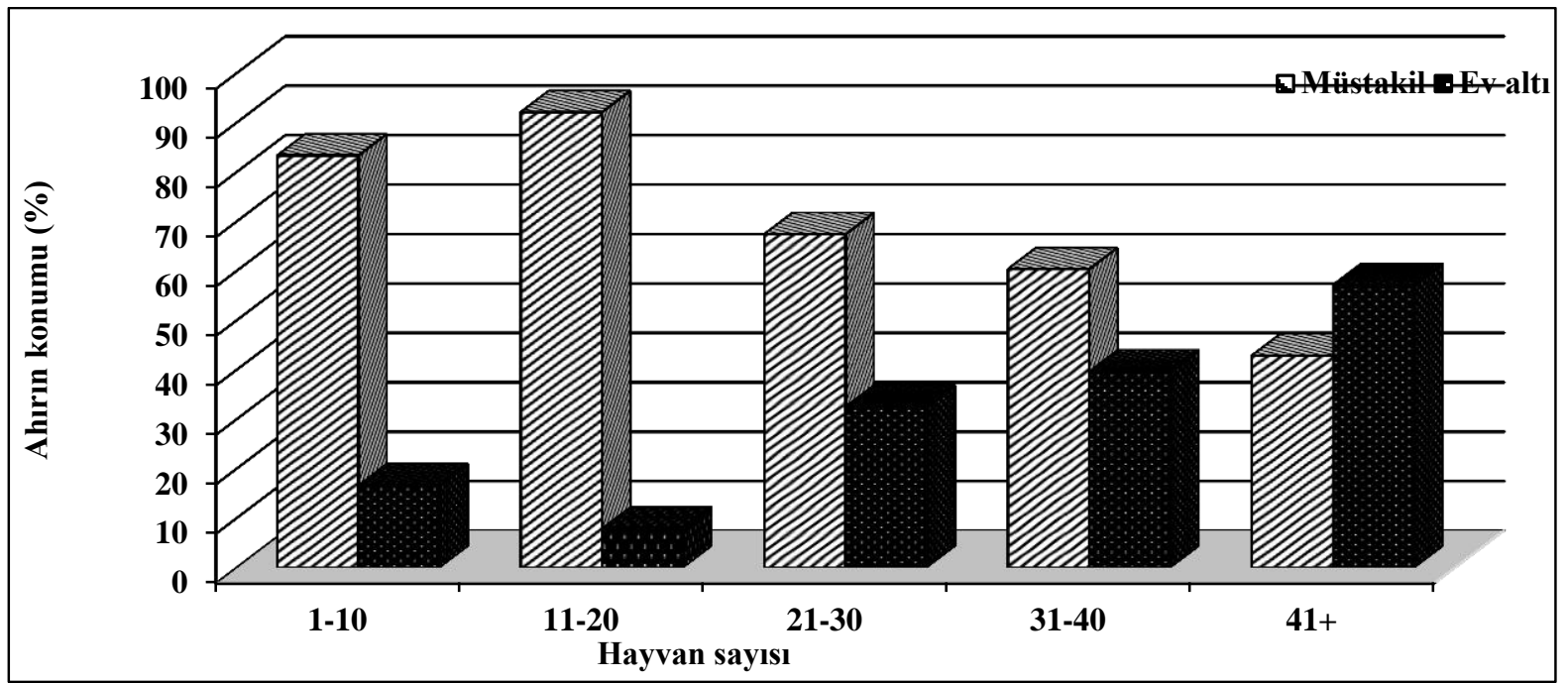

Şekil 2. Hayvan sayısına göre ahırın konumu

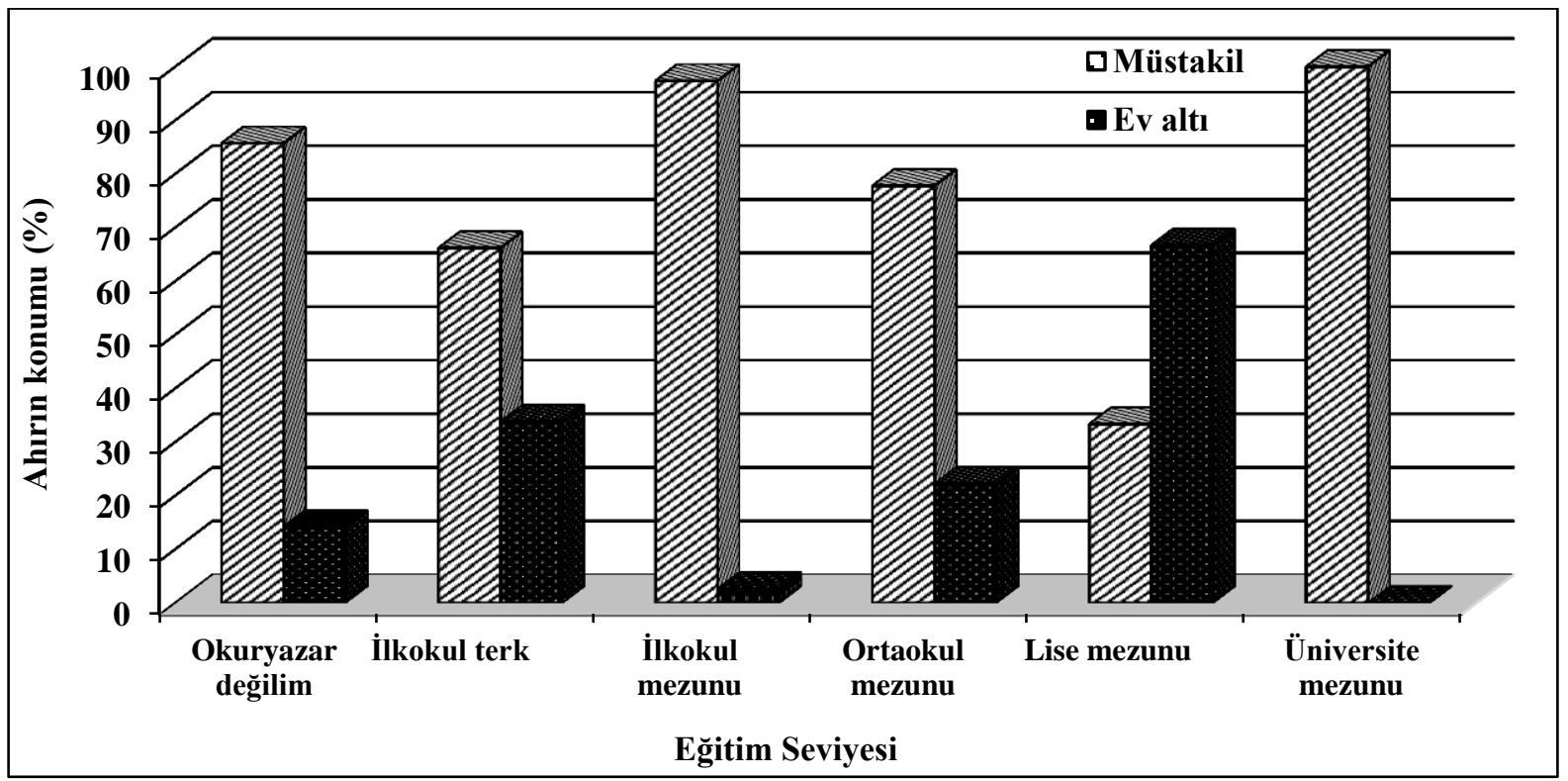

Şekil 3. Eğitim seviyesine göre ahırın konumu

Çizelge 5. Deneyim süresi ve ahır konumu

\begin{tabular}{|c|c|c|c|c|c|c|c|c|c|c|}
\hline \multirow[b]{3}{*}{ Ahır Konumu } & \multicolumn{8}{|c|}{ Deneyim süresi (yıl) } & & \\
\hline & \multicolumn{2}{|c|}{ 0-10 yıl } & \multicolumn{2}{|c|}{ 11-20 yil } & \multicolumn{2}{|c|}{ 21-30 yil } & \multicolumn{2}{|c|}{$30+y l$} & \multicolumn{2}{|c|}{ Toplam } \\
\hline & Adet & $\%$ & Adet & $\%$ & Adet & $\%$ & Adet & $\%$ & Adet & $\%$ \\
\hline Müstakil & 8 & 88.9 & 103 & 70.5 & 71 & 73.2 & 13 & 56.5 & 195 & 70.9 \\
\hline Ev alt1 & 1 & 11.1 & 43 & 29.5 & 26 & 26.8 & 10 & 43.5 & 80 & 29.1 \\
\hline \multirow[t]{2}{*}{ Toplam } & 9 & 100 & 146 & 100 & 97 & 100 & 23 & 100 & 275 & 100 \\
\hline & & & $X^{2}=3.9$ & $\mathrm{P}=\mathrm{C}$ & & & & & & \\
\hline
\end{tabular}


$\mathrm{Bu}$ sonuca göre yeni yapılan ahırların genellikle müstakil olarak yapıldığını, yetiştiricilerin deneyim süresi artsa da ev altı ahırlarını kullanmaya devam ettikleri söylenebilir. Deneyim süresi az olanların ya da hayvancilığa yeni başlayanların müstakil ahır oranlarının yüksek olması, insan refahı açısından genç yetiştiricilerin daha hassas davrandıkları, bu durumunda gençlerin bilgiye ulaşma ve yenilikleri kabul etme eğilimlerinin daha yüksek olduğu izlenimini uyandırmaktadır (Şekil 4).

Hınıs ilçesinde ahır duvarlarında kerpiç malzemenin $\% 45.6$ oranıyla en yaygın olarak kullanıldığ saptanmıştır. Bunu tuğla (\% 25.8), taş (\% 25.5), ahşap (\% 2.2) ve briket (\% 0.8) gibi duvar malzemeleri takip etmiştir (Çizelge 6).

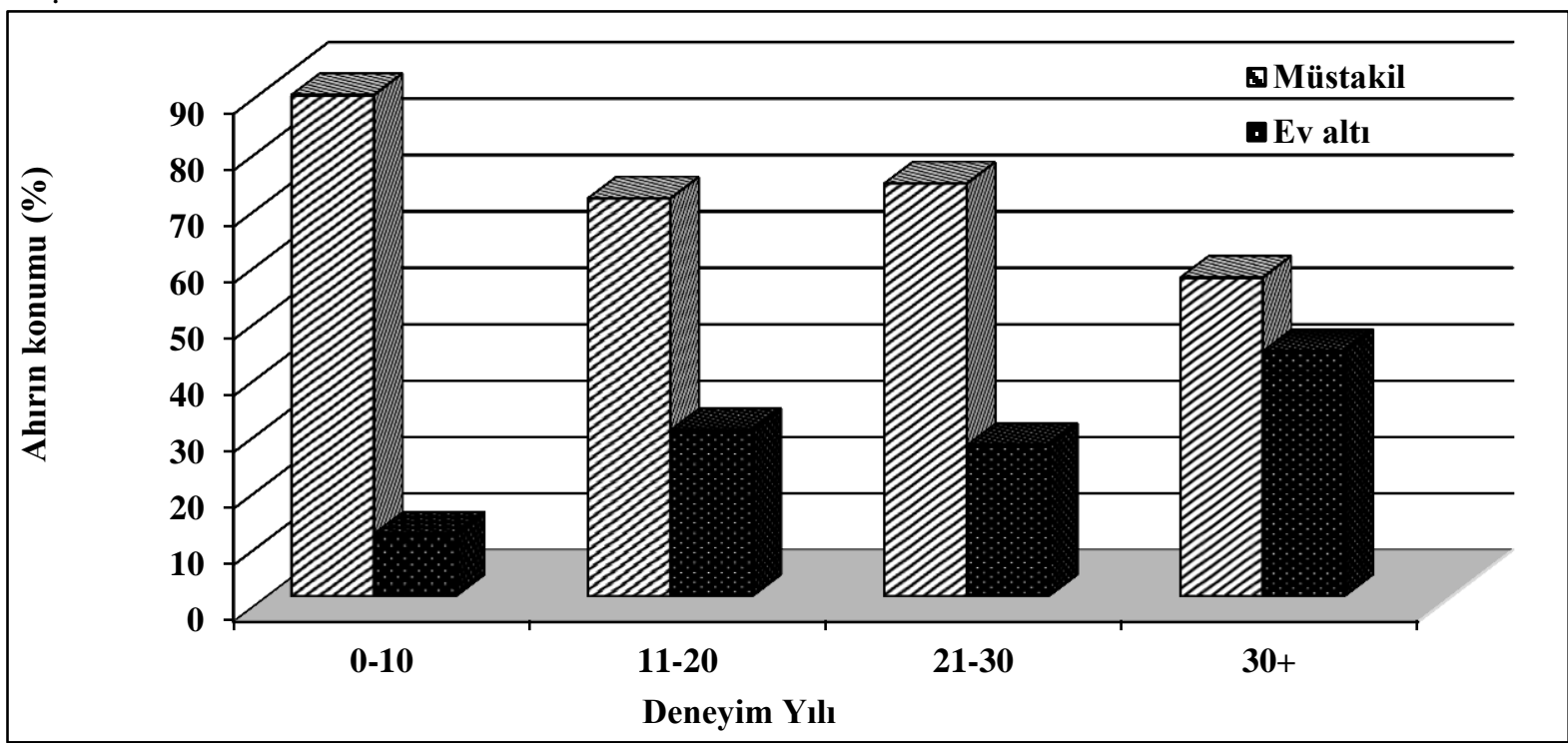

Şekil 4. Deneyim durumuna göre ahır konumu

Çizelge 6. Ahırda kullanılan yapı malzemeleri

\begin{tabular}{cccccccccccc}
\hline $\begin{array}{c}\text { Ahır } \\
\text { duvarları }\end{array}$ & Adet & $\boldsymbol{\%}$ & $\begin{array}{c}\text { Ahır } \\
\text { çatısı }\end{array}$ & Adet & $\boldsymbol{\%}$ & $\begin{array}{c}\text { Ahır } \\
\text { tabanı }\end{array}$ & Adet & \% & Yemlik & Adet & \% \\
\hline Taş & 93 & 25.5 & Sac & 56 & 15.3 & Beton & 184 & 50.0 & Beton & 219 & 61.2 \\
Kerpiç & 166 & 45.6 & Toprak & 140 & 38.1 & Taş & 121 & 32.9 & $\begin{array}{c}\text { Ahşap } \\
\text { (Tahta) }\end{array}$ & 139 & 38.8 \\
Tuğla & 94 & 25.8 & Beton & 123 & 33.5 & Toprak & 51 & 13.9 & & & \\
Briket & 3 & 0.8 & Briket & 4 & 1.1 & Tahta & 12 & 3.2 & & \\
$\begin{array}{c}\text { Ahşap } \\
\text { kereste) }\end{array}$ & 8 & 2.2 & $\begin{array}{c}\text { Ahşap } \\
\text { (kereste) }\end{array}$ & 30 & 8.2 & & & & & & \\
\hline Diğer & 14 & 3.8 & & & & & & \\
\hline
\end{tabular}

Duvar yapımında kerpiç kullanımının Hınıs'ta yüksek oranda tercih edildiği ortaya çıkmaktadır. Öte yandan kerpiç kullanımı Kahramanmaraş ilinde \% 26 (Kaygısız ve Tümer, 2009); Erzincan'ın Çayırlı ilçesinde \% 23.5 (Özyürek ve ark., 2014) olarak bildirilirken öte yandan Giresun ilinde bu oran \% 1.1 (Tugay ve Bakır, 2006) olarak rapor edilmiştir. Hınıs ilçesinde kerpicin duvar yap1 malzemesi olarak kullanılmasında, muhtemelen kerpicin diğerlerine göre daha bol ve ekonomik olarak sağlanması ve yöredeki alışkanlıkların önemli rolü olduğu söylenebilir.

Çalışma bulgularının aksine Türkiye'nin çeşitli yörelerinde yapılan anket çalışmalarında briket ve taş malzemenin ahır duvar inşaatında daha yüksek oranda kullanıldığı tespit edilmiştir. Duvar yapı malzemesi olarak briketin Kahramanmaraş (Kaygısız ve Tümer (2009), Bitlis (Bayraktar ve ark., 2010) ve Ağrı illerinde sirasiyla \% 40.0, \% 61.0 ve \% 42.5 oranlariyla en yüksek seviyede kullanıldığı, taş malzemenin ise Erzurum merkez ilçesinde (Erkmen ve ark., 2000), Giresun (Tugay ve Bakır 2006), Diyarbakır Ergani ilçesinde (Han ve Bakır, 2010), Muş (Şeker ve ark., 2012), Kars (Tilki ve ark., 2013), Erzincan'ın Çayırlı ilçesinde (Özyürek ve ark., 2014), Bingöl (Daş ve ark., 2014) illerinde sirasiyla \% 66.9, \% 62.3, \% 62.9, \% $42.1, \% 39.8, \% 41.7$ ve \% 50.0, oranlariyla en yüksek düzeyde kullanıldığı bildirilmiştir. Aydın ilinde ise tuğla ve delikli tuğla kullanımı \% 62.6 ve \% 34.4 oranlarında (Bardakçıŏglu ve ark., 2004) ilk sırada kullanıldığı, Ağrı ili (Bakan, 2014), Erzincan'ın Çayırlı ilçesi (Özyürek ve 
ark., 2014) ve Bingöl İllerinde (Daş ve ark., 2014) ise sirasiyla \% 16.9, \% 10.1 ve \% 20.0 oranlariyla daha düşük oranlarda kullanıldığı belirlenmiştir.

Hınıs ilçesinde ahırların çatısında kullanılan en yaygın yap1 malzemesi \% 38.1 oranıla toprak olup, bunu beton (\% 33.5), sac malzeme (\% 15.3), daha düşük oranlarda ise ahşap $(\%$ 1.1) ve diğer malzemeler $(\%$ 3.8) izlemiştir (Çizelge 6). Sac çatı materyali ise Ağrı'da \% 94.3 (Bakan, 2014), Erzincan Çayırlı'da \% 64.7 (Özyürek ve ark., 2014) ve Aydın ilinde \% 56.5 (Bardakçıŏlu ve ark., 2004), olarak bildirilmiş olup bu değerlerin çalışma bulgularından daha yüksek olduğu görülmektedir. Hınıs ilçesinde ahırlar genellikle tek katlı ve kerpiçten yapıldığından çatı olarak nitelendirdiğimiz tavanın da daha çok toprak ve betondan oluştuğu görülmektedir. Bu sonucun çiftçilerin alışkanlıklarından veya ekonomik durumundan kaynaklandığı düşünülmektedir.

Hayvan barınaklarının tabanının stabil, geçirimsiz, kimyasal madde ve idrara karşı dayanıklı ve kolay temizlenebilir olması gerektiği, en ekonomik taban malzemesinin sıkıştırılmış toprak olduğu ancak, hayvan ve gübre temizliği açısından tabanın beton olmasının tercih edildiği belirtilmektedir (Y1ldız, 2013, Özhan ve ark., 2009). Bu çalışmada ahır tabanında en fazla tercih edilen yap1 malzemesi \% 50.0 ile beton olduğu saptanmıştır. Bunun yanında işletmelerin \% 32.9'u taş zemin ve \% 13.9'u da toprak zemini tercih etmektedirler. Tahta taban ise çok düşük (\% 3.2) oranda tercih edilmektedir (Çizelge 6).

Türkiye'de farklı yörelerde yapılan anket çalışmalarında beton zemin oranı, Diyarbakır'da \% 48.5 (Tutkun, 1999) ve Giresun'da \% 47.5 (Tugay ve Bakır, 2006) olarak bildirilmiş, bahsedilen bulguların çalışma bulguları ile uyumlu olduğu görülmüştür. Ahır tabanında beton zeminin, Ankara'da \% 76.7 (Şahin, 1994), Aydın ilinde \% 71.7 (Bardakçığlu ve ark., 2004), Kahramanmaraş'ta \% 67 (Kaygısız ve Tümer, 2009), Muş ilinde \% 59.0 (Şeker ve ark., 2012), Şanlıurfa'da \% 85.2 (Yener ve ark., 2013), Ağrı'da \%
92.4 (Bakan, 2014) ve Erzincan'ın Çayırlı ilçesinde \% 93.3 (Özyürek ve ark., 2014) oranlarında daha yaygın olarak tercih edildiği ortaya konmuştur. ABD'de Pennsilvanya eyaletindeki sığır işletmelerinin \% 74.4 oranı ile beton zeminin ahır tabanında yaygın olarak tercih edilen zemin tipi olduğu bildirilmiştir (Vasseur ve ark., 2010).

Yemlikte yapı malzemesi olarak, işletmelerin \% 61.2'si beton ve \% 38.8'i ahşap yap1 malzemesi kullanmışlardır (Çizelge 6). Yapılan diğer çalışmalarda da, yemlikte beton yapı malzemesi kullanımının daha yaygın olduğu bildirilmiştir. Nitekim Ankara'da işletmelerin \% 98.4'ünde, Aksaray'da \% 89.4'ünde (Tatar, 2007), Bitlis ili Ahlat ilçesinde işletmelerin tümünde (Bayraktar ve ark., 2010) yemliklerin betondan yapıldı ̆̆

Yapılan anket sonuçlarına göre işletmelerin \% 40.0'1nda 4 adet, $\% 36.3$ 'ünde 3 adet, $\% 11.5$ 'inde 2 adet, \% 3.0'ünde ise 1 adet pencere bulunduğu belirlenmiştir. Beş adet \% 6.0, altı adet \% 2.7 ve 7 adet pencereye sahip işletme oranı ise \% 0.5 olmuştur (Çizelge 7). Genellikle 3-4 pencere bulunan işletme oranının daha yaygın olduğu görülmüştür. Tilki ve ark. (2013) tarafından Kars ilinde 43 (\% 10.4) işletmeye ait ahırlarda pencere bulunmadığını, 23 (\% 5.5) işletmede ise yalnızca 1 adet pencerenin olduğunu ve işletmelerin genelinde kış şartlarının ağır olması gerekçesi ile pencere ebatlarının standartların altında olduğu bildirilmiştir.

İşletmelerin \% 7.4'ünde 1 adet, \% 29.3'ünde 2 adet, $\% 32.1$ 'inde 3 adet, \% 27.1'sinde 4 adet, \% 3.3'ünde 5 adet, \% 0.8 'inde ise 6 adet ve üzerinde havalandırma bacası bulunduğu tespit edilmiştir (Çizelge 7). Ahırda havalandırma bacası sayısı ahır içindeki ısınan havanın, kötü kokuların ve gazların uzaklaştırılması için önemlidir. Genellikle Hınıs'taki sı̆̆ırcılık işletmelerinde 2,3 , ve 4 adet bacaya sahip olan ahır oranının daha fazla olduğu görülmektedir. 1-4 arası havalandırma bacası olanların oranı \% 95.4, 5-6 bacaya sahip işletmelerin oranı ise \% 4.7 olarak hesaplanmıştır.

Çizelge 7. Ahırda bulunan pencere, havalandırma bacası sayısı ve aydınlatma durumu

\begin{tabular}{ccccccccc}
$\begin{array}{c}\text { Pencere } \\
\text { sayısı }\end{array}$ & Adet & $\%$ & $\begin{array}{c}\text { Havalandırma } \\
\text { bacası sayısı }\end{array}$ & Adet & $\%$ & $\begin{array}{c}\text { Gündüz } \\
\text { aydınlatma } \\
\text { durumu }\end{array}$ & Adet & \% \\
\hline 1 & 11 & 3.0 & 1 & 27 & 7.4 & Doğal & 233 & 63.5 \\
2 & 42 & 11.5 & 2 & 107 & 29.3 & Elektrik & 134 & 36.5 \\
3 & 133 & 36.3 & 3 & 117 & 32.1 & & & \\
4 & 146 & 39.9 & 4 & 99 & 27.1 & & & \\
5 & 22 & 6.0 & 5 & 12 & 3.3 & & & \\
6 & 10 & 2.7 & $6+$ & 3 & 0.8 & & & \\
7 & 2 & 0.5 & & & & & & \\
\hline
\end{tabular}

Benzer sonuçlar Bakan (2014) tarafindan da bildirilmiş olup Ağrı'daki işletmelerde mevcut barınakların \% 96.2'sinde havalandırma bacası bulunduğu, \% 3.7'sinde havalandırma bacası olmadığg1, 1 ile 4 arası havalandırma bacası olanların oranını \% 97.0, havalandırma bacası sayısı 4 ve üzeri olanların 
oranının ise \% 2.9 olduğu bildirilmiştir. Baca sayısının yanında bacaların açık tutulması ve havalandırmanın yeterli olması da önemlidir. Nitekim Tilki ve ark. (2013) Kars ilinde Anket uygulaması yapılan 26 (\% 6.3) işletmeye ait ahırda hiç havalandırma bacası olmadığı, 15 (\% 3.6) işletmede ise yalnızca 1 adet havalandırma bacası olduğunu tespit etmişlerdir. Mevcut havalandırma bacalarının da genellikle yetersiz ölçülerde olduğu belirtilmiştir. Akyüz (1998) Van yöresinde işletmelerin \% 76.0'sında çeşitli şekillerde havalandırma bacaları bulunduğunu, ancak barınakların $\% \quad 86.0$ 'sında havalandırmanın yeterli olmadığını bildirmiştir. Havalandırma bacası bulunmasına rağmen havalandırmanın yeterli olmadığını, bunun sebebinin ise havalandırma bacalarının ve pencerelerin birçok işletmede ahırın soğuk olması nedeniyle kışın kapalı tutulmasından kaynaklandığg belirtilmektedir.
Hınıs'ta incelenen ahırlarda aydınlatmanın \% 63.5 oranında doğal olarak, \% 36.5 oranında elektrik ile sağlandığ 1 tespit edilmiştir (Çizelge 7). Doğal aydınlatma oranı Van ilinde Bakır (2002) tarafindan bildirilen \% 100 değeri ve Uşak ilinde (Köse, 2006) bildirilen \% 88.0 oranından düşük bulunmuştur. Bingöl ilinde ise ahırların tamamına yakınının elektrikle aydınlatıldığı ve güneş 1şı̆̆ından yararlanarak aydınlanma sağlayan ahır sayısının çok az sayıda olduğu bildirilmiştir (Daş ve ark., 2014).

İncelenen işletmelerde hayvanlara su verme işlemi, taşıma (\% 34.3) ve yemliklere su doldurma ( $\% 34.3)$ şeklinde yapılmakta olup ahırların \% 22.4'ünde otomatik suluklar ile gerçekleştiği saptanmıştır. Köy çeșmesi ve yalakların kullanımı ise mevcut işletmelerin $\%$ 8.9'u oranında görülmektedir (Çizelge 8).

Çizelge 8. Hayvanlara su verme şekli ve sıklığı

\begin{tabular}{|c|c|c|c|c|c|}
\hline $\begin{array}{c}\text { Hayvanlara su } \\
\text { verme şekli }\end{array}$ & Adet & $\%$ & $\begin{array}{c}\text { Hayvanlara su verme sıklığı } \\
\text { (gün) }\end{array}$ & Adet & $\%$ \\
\hline Yalak & 16 & 4.3 & 1 defa & 70 & 19.0 \\
\hline Otomatik suluk & 83 & 22.4 & 2 defa & 142 & 38.5 \\
\hline Taşıma & 127 & 34.3 & 3 defa & 147 & 39.8 \\
\hline Köy çeşmesi & 17 & 4.6 & 3'den fazla & 10 & 2.7 \\
\hline Yemliklere su doldurma & 127 & 34.3 & & & \\
\hline Toplam & 370 & 100 & Toplam & 369 & 100 \\
\hline
\end{tabular}

Çalışma bulgularının aksine, Bakan (2014) Ağrı'da (\% 94.3) ve Daş ve ark. (2014) Bingöl'de (\% 100.0) yüksek oranda yalakların sulama amaçlı kullanıldığını bildirmişlerdir. Yemliklere su doldurma yöntemi; Bakır (2002)'ın Van ilindeki işletmelerde \% 22.0 ve Yıldız (1988)'ın Adana'nın Çukurova ilçesindeki işletmelerde \% 15.0 olarak bildirdiği değerlerden yüksek bulunmuştur. Taşıma yöntemi ise, Akyüz (1998)'ün bildirdiği değerden (\% 76.0) düşük bulunmuştur. Köy çeşmesi veya dışarıda sulama yöntemi ise Bakır (2002) Van ilinde \% 69.0, Yıldız (1988) Çukurova'da \% 85.0 değerlerinden düşük bulunmaktadır. Hayvanların istedikleri zaman, istedikleri miktarlarda su içmelerine olanak sağlayan otomatik suluk uygulamalarının Hınıs ilçesinde nispeten düşük olma gerçeği ( $\%$ 22.4) Türkiye'de yapılan diğer çalışmalarda da rapor edilmiştir. Bu oran, Ankara'da, Aksaray'da (Tatar, 2007) ve Van yöresindeki özel işletmelerde (Bakır, 2001) sirasiyla \%18.0, \%10.6 ve $\% 9.0$ olarak bildirilmiştir.

İşletmelerin \% 39.8'i hayvanlarını günde $3 \mathrm{kez} \mathrm{su}$ verdiklerini, \% 38.5'inin günde $2 \mathrm{kez,} \% 19.0$ 'unun ise $1 \mathrm{kez}$ suya ulaşabilme imkanı sağlandığını, \% 2.7'sinde ise günde 3 den fazla su verildiği tespit edilmiştir (Çizelge 8). Süt sığırlarının su ihtiyacı, hayvanın vücut ağırlığına, süt verimine, verilen yemin cinsine ve çevre sıcaklığı gibi birtakım faktörlere bağlı olarak değişmektedir. Bir süt ineği, doğası gereği günlük ortalama $10 \mathrm{kez}$ su içtiği ve bu ineğin yaşama payı minimum su ihtiyacının günlük 45-55 litre kadar olduğu, çok sicak havalarda bu ihtiyacın \% 80 arttığ 1 , her litre süt verimi içinde 4 litre daha fazla suya ihtiyaç duyulduğu suyun hayvanların sürekli olarak yanında bulundurulmasının daha faydalı olduğu dikkate alındığında (Özhan ve ark., 2009), Hınıs ilçesindeki yetiştiricilerin çoğunluğunun (\% 77.2) hayvanlara yeterli su vermede yetersiz olduğu söylenebilir.

\section{Barındırma Özellikleri}

Buzağı bölmesi işletmelerin \% 50.0'sinde farklı ahırda ayrı bölmede, \% 26.5'inde aynı ahırda ayr1 bölmede, \% 17.3'ünde aynı ahırda bireysel buzağ 1 bölmesinde barındırıldığı, \% 5.9'unda ise aynı ahırda ana ile barındırıldığı tespit edilmiştir (Çizelge 9).

Hınıs'ta bulunan işletmelerde buzağıları aynı ahırda ayrı grup bölmesinde serbest barındırma oranı Bardakçığlu ve ark. (2004) Aydın ilinde \% 93.9, Tilki ve ark. (2013) Kars ilinde \% 76.6, ve Bakan (2014) Ağr1 ilinde $\% \quad 100.0$ olarak bildirdiği değerden düşük bulunmuştur. Bir başka deyişle, yaygınlık bakımından Hınıs'ta ikinci sırayı almasına karşın, Türkiye genelinde aynı ahırda ayrı grup bölmesinde buzağı barındırmanın yaygın olarak uygulandığı söylenebilir. 
Çizelge 9. Ahırda buzağı ve doğum bölmesi durumu

\begin{tabular}{cccccc}
\hline Buzağı bölmesi & Adet & \% & Doğum bölmesi & Adet & \% \\
\hline Aynı ahırda ayrı grup bölmesinde & 95 & 26.5 & Var & 93 & 25.1 \\
Aynı ahırda ana ile & 21 & 5.9 & Yok & 277 & 74.9 \\
Aynı ahırda ferdi buzağı bölmesinde & 62 & 17.3 & & & \\
Farklı ahırda ayrı bölmede & 179 & 50.0 & & & \\
Diğer & 1 & 0.3 & & $\mathbf{3 7 0}$ & $\mathbf{1 0 0}$ \\
\hline Toplam & $\mathbf{3 5 8}$ & $\mathbf{1 0 0}$ & Toplam & &
\end{tabular}

Bireysel bölme oranı ise Vasseur ve ark. (2010) tarafindan Kanada'da \% 87.9 ve ABD de \% 67.0 olarak bildirilen değerlerden düşük bulunmuştur. Ayrı ahırda, bireysel bölmelerde buzağı yetiștiriciliği uygulamasının Türkiye'de birçok yöredeki orandan daha yüksek, ancak Kanada ve ABD deki uygulamalardan daha düşük olduğu saptanmıştır.

İlçedeki işletmelerin büyük çoğunluğunda (\% 74.9) inekler için doğum bölmesi olmadığı, ancak \% 25.1'inde doğum bölmesi olduğu saptanmıştır (Çizelge 9). Yörede ahırlarda doğum bölmesi bulunma oranı, Kaygısız ve Tümer (2009)' in Kahramanmaraş ilinde \% 30.0 değeri ile benzer, Yener ve ark. (2013)'nın Şanlıurfa ilinde bildirilen \% 83.0 ve Bardakçıoğlu ve ark. (2004) Aydın ilinde \% 45.5 değerinden düşük, Önal ve Özder (2008)'in Edirne ilinde bildirilen \% 3.5 değerinden yüksek bulunmuştur. Tilki ve ark. (2013) Kars ilinde işletmelerin \% 82.7'sinde düve ve inekler için doğum bölmesi bulunmadığını ahır içerisinde bulundukları yerde doğum yaptıklarını bildirmişlerdir.

İlçedeki işletmelerin büyük çoğunluğu düve, dana ve kurudaki inekleri birlikte (\% 84.3) barındırdıkları sadece \% 15.7 'sinin ayrı ayrı barındırıldığ 1 ortaya konulmuştur (Çizelge 10). Hayvan sayısı arttıkça farklı yaş grubundaki ayrı bulundurma oranında önemli bir artış olduğu görülmüştür $(\mathrm{P}<0.01)$.

Yataklık kullanma, temizlik ve gübre değerlendirme durumu

Hınıs ilçesinde işletmelerin \% 81.0'inin yataklık kullanmadıkları, \% 19.0'unun yataklık kullandığ 1 saptanmıştır (Çizelge 11). Benzer şekilde, Uşak ilindeki işletmelerin \% 92'sinde (Köse, 2006), Ankara ili Ayaș ilçesinde işletmelerin \% 89.3'ünde (Şahin, 1994), Diyarbakır ilinde \% 93.4'ünde (Han ve Bakır, 2010) ve Muş ilinde ise işletmelerin \% 55.9'unda (Şeker ve ark., 2012) yataklık kullanılmadığı bildirilmiştir. Ancak Türkiye'de yataklık kullanımının yaygın olarak kullanıldığı iller de bulunmaktadır. Nitekim yataklık kullanma oranları Tokat ilinde \% 71.1 (Ildız, 1999), Van ilinde ithal kültür ırkı sığırı yetiştiren işletmelerde \% 52.5 (Bakır, 2002) ve Kahramanmaraş ilinde ise \% 90.0 (Kaygısız ve Tümer, 2009) olarak saptanmıştır.

Çizelge 10. Düve, dana ve kurudaki inekleri barındırma durumu

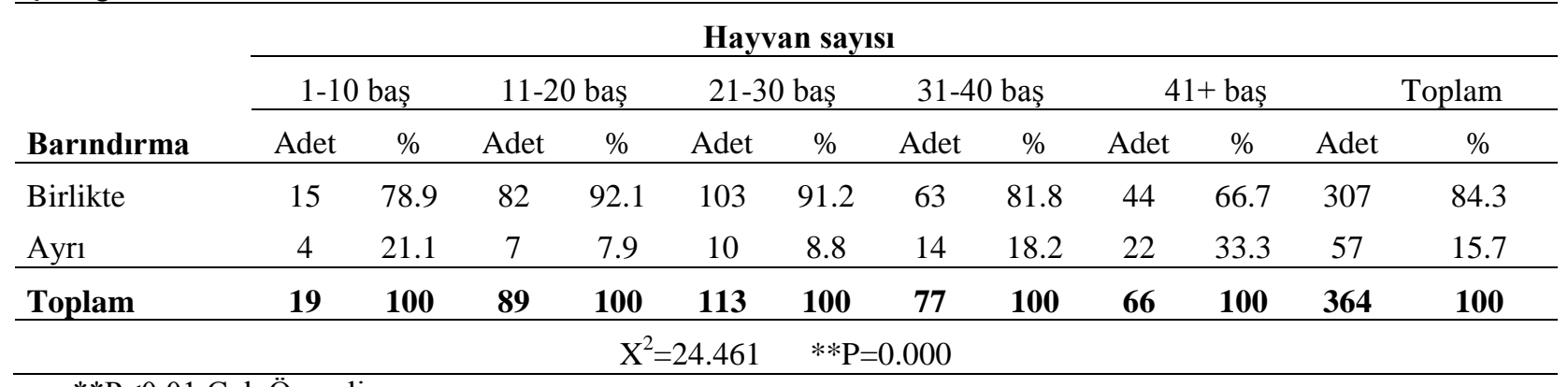

$* * \mathrm{P}<0.01$ Çok Önemli

Çizelge 11. Ahırda yataklık kullanma durumu ve kullanılan yataklık çeşitleri

\begin{tabular}{cccccc}
\hline $\begin{array}{c}\text { Yataklık kullanma } \\
\text { durumu }\end{array}$ & Adet & \% & $\begin{array}{c}\text { Ahırda kullanılan Yataklık } \\
\text { çeşitleri }\end{array}$ & Adet & \% \\
\hline Evet & 70 & 19.0 & Hububat sapı & 20 & 16.7 \\
Hayır & 299 & 81.0 & Hububat samanı & 14 & 11.7 \\
& & & Kuru gübre (fişkı) & 76 & 63.3 \\
& & & Diğer & 10 & 8.3 \\
\hline Toplam & $\mathbf{3 6 9}$ & $\mathbf{1 0 0}$ & Toplam & $\mathbf{1 2 0}$ & $\mathbf{1 0 0}$ \\
\hline
\end{tabular}

Yörede genellikle yataklık kullanılmaması büyük bir eksiklik olarak görülmektedir. Nitekim, yataklık kullanılması bilindiği gibi hayvanların diz yaralanmalarını, kirlenmelerini önlediği gibi, memelerin ve vücudun kuru kalmasını sağladığ 
1s1 kaybını da önlediği bildirilmektedir (Özhan ve ark. 2009).

Hınıs ilçesinde incelenen işletmelerin yataklık çeşidi olarak daha çok kuru gübreyi (\% 63.3) yaygın olarak kullandıkları tespit edilmiştir. Hububat sapı (\% 16.7), saman (\% 11.7) ve diğer altlığın ( $\%$ 8.3) daha az oranlarda tercih edildiği tespit edilmiştir (Çizelge 11). Doğu Anadolu bölgesinde sap saman gibi kaba yemler daha çok hayvan yemlemede kaba yem kaynağı olarak kullanıldığından değerli bulunmaktadır. Bunun sonucu olarak sap ve samanın yataklık olarak kullanımı pek yaygın değildir. Bölgede daha ekonomik olan ve yaygın olarak bulunan kuru gübre kullanımının yüksek oranda olduğu görülmektedir. Kuru gübre kullanımının Aksaray'da \% 69.1 oranı ile en yaygın yataklık malzemesi olduğunu bildiren Tatar (2007) ile bulgularımız benzer bulunmuştur. Araştırmada, sap ve saman kullanım oranlarının toplamının \% 28.4 olduğu ve bu değerin Yayar ve Karkacier (1996) in bulgularından düşük (Tokat ilinde \% 48.9) ve Yener ve ark. (2013) nın verilerinden daha yüksek (Şanlıurfa'da \% 20.5) olduğu saptanmıştır. Söz konusu sap ve samanın yataklık olarak kullanımı gelişmiş ülkelerde çok daha yüksek oranlarda olduğu Heinrichs ve ark. (1987) (\% 57.2) ve Vasseur ve ark. (2010) (\% 65.4) tarafindan rapor edilmiştir.

Çalışma kapsamında değerlendirilen işletmelerin \% 40.5'inin haftada $3 \mathrm{kez}, \% 29.7$ 'sinin haftada $2 \mathrm{kez}$ yataklık değiştirdikleri saptanmış olup, işletmelerin çok az bir kısmının haftada 4 kez (\% 11.2) ve haftanın her günü $(\% \quad 10.4)$ altlığı değiștirdikleri belirlenmiştir. Haftada 1 (\% 5.2), haftada 5 (\% 1.7) ve haftada $6 \mathrm{kez}$ (\% 0.9$)$ yataklık değiştirenlerin oranı çok daha düşük düzeylerde gerçekleşmiştir (Çizelge 12).

Yataklık kullanmayan işletmelerin \% 53.3'ü günde 3 kez, \% 27.8'i günde $1 \mathrm{kez} \%$ 11.1'i günde $2 \mathrm{kez} \%$ 7.8'i ise gün aşırı bir kez hayvanların altını temizledikleri tespit edilmiştir (Çizelge 12). Bölgede ahır temizliği konusunda yetiştiricilerin gereken özeni gösterdikleri söylenebilir. Hınıs ilçesinde günde $3 \mathrm{kez}$ ahır temizliği yapılan işletmelerin oranı Han ve Bakır (2010)'ın Diyarbakır ili Ergani ilçesindeki \% 83.8 oranından düşük, Kaygısız ve Tümer (2009)'in Kahramanmaraş ilinde bildirdiği \% 34.0 oranından yüksek, günde $2 \mathrm{kez}$ yapılan temizlik oranından $(\%$ 47.0) ise düşük bulunmuştur.

Hınıs'ta İşletmelerin \% 39.0'u ahırlarında yılda 3 kez, \% 30.1'i y1lda $2 \mathrm{kez}, \%$ 17.1'i yılda $1 \mathrm{kez}$ genel temizlik yaparken \% 12.2 si yılda 4 kez, \% 1.6's1 ise yılda $5 \mathrm{kez}$ genel temizlik yapmaktadırlar (Çizelge 12). İşletmelerin yılda en az $2 \mathrm{kez}$ ve üzerinde genel temizlik yapmaları ahırdaki parazit ve enfeksiyon kaynaklarının uzaklaştırılması açısından önem arz ettiğinden Hınıs ilçesinde yılda $1 \mathrm{kez}$ genel temizlik yapılması uygun olmamakla birlikte yılda yetiştiriciler tarafından yılda en az 2 kez ve üzerinde (\%82.9) temizlik yapılması olumlu karşılanabilir.

İşletmelerin \% 84.1'inde ahırdaki gübrenin elle süpürme yoluyla temizlendiği, $\%$ 13.7'sinde ise otomatik gübre siyırıcılarla ve \% 2.2'si ise diğer araçlarla temizlendiği belirlenmiştir (Çizelge 13). Hınıs'ta çok büyük kapasiteli modern ve mekanizasyona uygun olan ahırlar fazla bulunmadığından, işletmecilerin işgücü kullanarak elle süpürme yoluyla temizlik yapmaları beklenen bir durumdur.

Kahramanmaraş ilinde elle süpürme ile gübre temizliği yapan işletmelerin daha yüksek oranda $(\%$ 97.0) olduğu bildirilirken (Kaygısız ve Tümer, 2009), otomatik gübre sıyırıcılarla gübre temizliği (\% 3.0) ise bulgularımızdan oldukça düşük olmuştur.

Çizelge 12. Yataklık değiştirme sıklığı ve yataklık kullanılmadığında ahır temizleme sıklığı ve yıllık genel temizlik sayis1

\begin{tabular}{|c|c|c|c|c|c|c|c|c|}
\hline $\begin{array}{c}\text { Yataklık } \\
\text { değiştirme } \\
\text { sıklığı }\end{array}$ & Adet & $\%$ & $\begin{array}{c}\text { Yataklık } \\
\text { kullanılmadığında ahır } \\
\text { temizleme sıklığı }\end{array}$ & Adet & $\%$ & $\begin{array}{l}\text { Yıllık genel } \\
\text { temizlik } \\
\text { sayısı } \\
\end{array}$ & Adet & $\%$ \\
\hline Haftada 1 gün & 12 & 5.2 & Günde bir kez & 93 & 27.8 & $1 \mathrm{kez}$ & 63 & 17.1 \\
\hline Haftada 2 gün & 69 & 29.9 & Günde iki kez & 37 & 11.1 & $2 \mathrm{kez}$ & 111 & 30.1 \\
\hline Haftada 3 gün & 94 & 40.7 & Günde üç kez & 178 & 53.3 & $3 \mathrm{kez}$ & 144 & 39.0 \\
\hline Haftada 4 gün & 26 & 11.3 & İki günde bir kez & 26 & 7.8 & $4 \mathrm{kez}$ & 45 & 12.2 \\
\hline Haftada 5 gün & 4 & 1.7 & & & & $5 \mathrm{kez}$ & 6 & 1.6 \\
\hline Haftada 6 gün & 2 & 0.9 & & & & & & \\
\hline Haftada 7 gün & 24 & 10.4 & & & & & & \\
\hline Toplam & 232 & 100 & Toplam & 334 & 100 & Toplam & 369 & 100 \\
\hline
\end{tabular}


Çizelge 13. Ahırda gübreyi temizleme şekli, depolama yeri ve değerlendirme şekli

\begin{tabular}{|c|c|c|c|c|c|c|c|c|}
\hline $\begin{array}{l}\text { Ahırda gübreyi } \\
\text { temizleme şekli }\end{array}$ & Adet & $\%$ & $\begin{array}{c}\text { Gübreyi } \\
\text { depolama yeri }\end{array}$ & Adet & $\%$ & $\begin{array}{c}\text { Gübreyi } \\
\text { değerlendirme şekli }\end{array}$ & Adet & $\%$ \\
\hline $\begin{array}{c}\text { Elle süpürme ve el } \\
\text { arabası ile }\end{array}$ & 312 & 84.1 & $\begin{array}{l}\text { Ahır yakınında } \\
\text { açıkta }\end{array}$ & 293 & 80.3 & Yakacak & 50 & 13.4 \\
\hline $\begin{array}{l}\text { Otomatik mekanik } \\
\text { siyırıcılarla }\end{array}$ & 51 & 13.7 & $\begin{array}{l}\text { Dişarıda gübre } \\
\text { çukurunda }\end{array}$ & 61 & 16.7 & Satış & 44 & 11.8 \\
\hline Diğer & 8 & 2.2 & Diğer & 11 & 3.0 & $\begin{array}{c}\text { Tarlada gübre olarak } \\
\text { Hepsi }\end{array}$ & $\begin{array}{c}260 \\
18\end{array}$ & $\begin{array}{r}69.9 \\
4.8 \\
\end{array}$ \\
\hline Toplam & 371 & 100 & Toplam & 365 & 100 & Toplam & 372 & 100 \\
\hline
\end{tabular}

Hınıs'ta ankete katılan işletmelerin gübreyi çok büyük oranda ahır yakınında açıkta (\% 80.3) depoladıkları, az bir kısmının (\% 16.7) dışarıda gübre çukurunda, \% 3.0'ü ise diğer alanlarda depoladıkları belirtilmiştir (Çizelge 13). Bu sonuçla, yörede gübrenin açıkta depolanması ve yaydığı kötü koku nedeniyle çevre kirliliğine neden olmakta, başta sinek gibi haşerelerin çoğalmasını kolaylaştırmakta, çeşitli bulaşıcı hastalıkların yayılmasına zemin hazırlamakta ve bu yüzden halk sağlığını olumsuz etkilemektedir. Benzer şekilde Tilki ve ark. (2013) tarafından da Kars ilindeki işletmelerin \% 81.0'inin hayvanlardan elde edilen gübreyi ahır yakınında biriktirerek depoladıkları bildirilmiştir. Gübre depolama yeri olarak Kanada'da (Sheppard ve ark., 2011) işletmelerin \% 53.0'ü betondan yapılmış çukurların, \% 39.0’u sığınak şeklindeki depoların ve \% 10'unun ise toprak üstü küçük depoların kullanıldığını bildirmişlerdir. Meyer ve ark. (1997) ise ABD'de Kaliforniya eyaletindeki işletmelerin \% 95.9 unun gübreyi gübre çukurlarında depoladıklarını rapor etmişlerdir.

Hınıs ilçesinde işletmeler gübreyi, \% 69.9'u tarlada gübre, \% 13.4' ü yakacak olarak, \% 11.8'i satarak ve \% 4.8'i ise hem gübre, hem yakacak hemde satış amaçlı değerlendirmektedirler (Çizelge 13). Gübrenin Burdur ilinde \% 88 (Özen ve Oluğ, 1997) ve Kahramanmaras ilinde (Kaygısız ve Tümer, 2009) \% 94.0 oranında tarlada değerlendirilmesinin daha yaygın olduğu bildirilmiştir. Dou ve ark. (2001) tarafindan
Pensilvanya'da işletmelerin \% 67.0 - \% 82.0'sinin genel itibariyle gübreyi katı veya paket şeklinde depoladığı, Sheppard ve ark. (2011) ise Kanada'da işletmelerin gübrenin hemen hemen tamamını bitkisel üretimde kullandıklarını ifade etmiş̧lerdir. Hınıs ilçesinde gübreyi yakacak olarak kullanma oranının Diyarbakır'da \% 52.1 (Han ve Bakır, 2010) ve Ağrı'da \% 88.78 (Bakan, 2014), olarak bildirilen değerlerden daha düşük olması olumlu bir davranış olarak değerlendirilebilir.

Hınıs'taki İşletmelerin \% 72.1'i kışın ahır içi Sıcaklığının 1lık, \% 27.3'ü ise sıcak, \% 0.6'sı ise serin olduğunu belirtmişlerdir (Çizelge 14). Ahır içi sıcaklığının 1lık olması halinde hayvanların rahat ettiği ve verimlerinin yükseldiğine inananların oranı $\% 84.0$ iken, rahatsız olur verimleri azalır diyen işletmelerin oranı da \% 16.0 olmuştur (Çizelge 14).

Hınıs ilçesinde ahır yapısının işletme sahiplerinin \% 88.8'inin sağlıklarını olumsuz etkilediği ifade edilmektedirler. İşletmecilerin \% 88.6's1 mevcut ahır yapısının hayvanların süt verimini ve \% 81.0'i ise hayvanların gelişimini olumsuz etkilediğini düşünmektedirler (Çizelge 15). Benzer şekilde Tilki ve ark. (2013) Kars ilinde ahırların yapısı nedeniyle işletme sahiplerinin \% 48.79'unun sağlıklarının olumsuz etkilendiğini, \% 60.92'sinin ahır yapısı nedeniyle hayvanların süt verimlerinin düşük olduğunu ve \% 57.04'ünün ahır yapısının hayvanların gelişimine olumsuz etkisi olduğunu rapor etmişlerdir.

Çizelge 14. Kışın ahır sıcaklığı ve ahır sıcaklığı 1lık olduğunda hayvanların etkilenme durumu

\begin{tabular}{cccccc}
\hline $\begin{array}{c}\text { Kışın ahır sıcaklığı } \\
\text { durumu }\end{array}$ & Adet & $\%$ & $\begin{array}{c}\left.\text { Kışın ahır sıcaklı̆̆ı ılık (15-16 }{ }^{\mathbf{C}} \mathbf{C}\right) \\
\text { olduğunda hayvanların etkilenme } \\
\text { durumu }\end{array}$ & Adet & $\%$ \\
\hline Sicak & 100 & 27.3 & Rahatsız olurlar, verimleri azalır & 59 & 15.9 \\
Ilık & 264 & 72.1 & Rahat ederler verimleri yükselir & 313 & 84.1 \\
Serin & 2 & 0.6 & Toplam & 372 & 100 \\
Toplam & 366 & 100 & &
\end{tabular}

Çizelge 15. Ahır yapısının işletmeci sağlığını, hayvanların süt verimini ve gelişimini olumsuz etkileme durumu

\begin{tabular}{ccccccc}
\hline & \multicolumn{2}{c}{ İşletmeci sağlığı } & \multicolumn{2}{c}{ Hayvanların süt verimi } & \multicolumn{2}{c}{ Hayvanların gelişimi } \\
\hline & Adet & $\%$ & Adet & $\%$ & Adet & $\%$ \\
\hline Etkiliyor & 332 & 88.8 & 334 & 88.6 & 299 & 81.0 \\
Etkilemiyor & 42 & 11.2 & 43 & 11.4 & 70 & 19.0 \\
\hline Toplam & $\mathbf{3 7 4}$ & $\mathbf{1 0 0}$ & $\mathbf{3 7 7}$ & $\mathbf{1 0 0}$ & $\mathbf{3 6 9}$ & $\mathbf{1 0 0}$ \\
\hline
\end{tabular}




\section{SONUÇ ve ÖNERILER}

Hınıs ilçesinde işletmelerin barınak ve çevre özellikleri ile ilgili olarak yapılan anket çalışması sonucunda elde edilen veriler işığında yapılan tespitler ve öneriler şöyle özetlenebilir; Hınıs ilçesinde yeni kurulacak işletmelerde serbest duraklı ahır modeline geçilmesi ve yaygınlaştırılması ahır maliyetinin nispeten düşük olması, yıllık bakım masraflarının az olması, işgücü ve zamandan tasarruf, etkili mekanizasyon uygulaması, ayrıca hayvan refahı ve sağlığı vb. gibi birçok bakımdan faydalı olacaktır. Mevcut ahırların, işletmeciler tarafından da yüksek oranda kabul gören olumsuz ahır koşullarının, ivedilikle ıslahı için ilgili resmi kurumlar tarafindan da teknik bilgi ve ekonomik desteklerin sağlanması gerekli görülmektedir. $\mathrm{Bu}$ bağlamda ahır duvarlarının depreme dayanıklı ve daha sağlıklı olması için kerpiç yerine briket veya tuğladan yapılması, ahır çatılarında ahşap üzerine sac malzeme kullanılması, ahırlarda doğal aydınlatmanın pencerelerden sağlanması, nem, koku ve sicaklığın azaltılması için mevcut bacaların uygun sayıda ve açık tutulması faydalı olacaktır.

Hayvanların diz yaralanmalarını, sakatlanmalarını ve mastitis vakalarını azaltmak ve dolayısıyla hijyenik bir üretim için yataklık kullanımının da yaygınlaşması gereklidir. Hayvanlara sürekli su temin edebilme imkânının sağlanması için otomatik suluk kullanılması veya ahır içine su tesisatı yapılmasının uygun olacağı söylenebilir. Yörede inekler için doğum bölmesi olmadığı tespit edilmiş olup sağlıklı buzağı yetiştirmek açısından buzağı bölmesi yapılması faydalı olacaktır. Bölgedeki işletmelere yapılacak bilgi desteği ve yatırım teşvikleri ile ayrıca bu amaçla ilgili kurumlarla işbirliği yapılarak yetiştirici eğitim çalışmaları yapılmasının işletmelerin karlı bir hayvancılık yapabilmelerine katkıda bulunabileceği düşünülmektedir.

\section{KAYNAKLAR}

Akyüz, A. 1998. Van Yöresi Aile İşletmelerinde Büyükbaş Hayvan Barınaklarının Durumu ve Geliştirme Olanakları. Ç.Ü. Fen Bil. Ens., Zootekni ABD, Doktora tezi.

Bakan, Ö. 2014. Ağrı İli Süt Sığırcılı̆̆ı İşletmelerinin Yapısal Özellikleri. Atatürk Üniversitesi Fen Bil. Ens., Zootekni ABD, Yüksek Lisans Tezi, $92 \mathrm{~s}$.

Bakır, G. 2001. Van iline ithal edilen kültür 1rk sığırların özel işletmelere adaptasyonu. Atatürk Ün. Zir. Fak. Dergisi, 32 (4): 415-427.

Bakır, G. 2002. Van İlindeki Özel Süt Sığırcılığı İşletmelerinin Yapısal Durumu. Yüzüncü Yıl Üniversitesi, Ziraat Fakültesi Tarım Bilimleri Dergisi, 12(2): 1-10.

Bardakçıŏlu, H.E., Türkyılmaz, M.K., Nazlıgül, A. 2004. Aydın İli Süt Sığırcılık İşletmelerinde Kullanılan Barınakların Özellikleri Üzerine Bir Araştırma. İstanbul Üniversitesi Veteriner Fakültesi Dergisi, 30(2): 51-62.
Bayraktar, H., Uğurlu, N., Yılmaz, A.M. 2010. Bitlis İli Ahlat ve Adilcevaz İlçeleri Süt Sığırı İşletmelerinde Barınakların Değerlendirmesi. Selçuk Tarım ve Gıda Bilimleri Dergisi, 24(2): 17-22.

Cochran, W.G. 1977. Sampling Techniques. 3rd Edition. John Wiley\&Sons. New York.

Daş, A., İnci, H., Karakaya, E., Şengül, A.Y. 2014. Bingöl İli Damızlık Sığır Yetiştiricileri Birliğine Bağlı Sığırcılık İşletmelerinin Mevcut Durumu. Türk Tarım ve Doğa Bilimleri Dergisi, 1(3): 421429.

Dou, Z., Galligan, D. T. , Ramberg, C. F., Meadows, C., Ferguson, J. D. 2001. A Survey of Dairy Farming in Pennsylvania: Nutrient Management Practices and İmplications. Journal of Dairy Science, 84(4): 966973.

Erkmen, Y., Çelik, A., Yıldız, C. 2000. Erzurum İli Süt Sığırcılığı İşletmelerinin Yapısal Durumu ve Ahır İçi Mekanizasyon Özellikleri Üzerine Bir Araştırma. Tarımsal Mekanizasyon 19. Ulusal Kongresi, 01-02 Haziran, Erzurum.

Han, Y., Bakır, G. 2010. Özel Besi İşletmelerinin Barınak Yapısı ve Etkileyen Faktörler. Atatürk Üniversitesi Ziraat Fakültesi Dergisi, 41(1): 45-51.

Heinrichs, A. J., Graves, R. E., Kiernan, N.E. 1987. Survey of Calf and Heifer Housing on Pennsylvania Dairy Farms. Journal of Dairy Science, 70: 19521957.

Ildız, F. 1999. Tokat İli Merkez İlçesinde İthal Sığır Yetiştiren Tarım İşletmelerinin Yapısı. A.Ü Fen Bil. Ens., Zootekni ABD, Yüksek Lisans Tezi, Ankara.

Kaygısız, A., Tümer, R. 2009. Kahramanmaraş İli Süt Sığırı İşletmelerinin Yapısal Özellikleri; 2. Barınak Özellikleri. KSÜ Doğa Bilimleri Dergisi, 12(1): 40-47.

Köse, K. 2006. Uşak İli Damızlık Sığır Yetiştiriciler Birliğine Kayıtlı İşletmelerin Genel Yapısı. Trakya Üniversitesi Fen Bil. Ens., Zootekni ABD Yüksek Lisans Tezi. $84 \mathrm{~s}$.

Meyer, D.M., Garnett, I., Guthrie, J.C. 1997. A Survey of Dairy Manure Management Practices in California. Journal of Dairy Science, 80(8): 18411845 .

Newbold, P. 1995. Statistics for Business and Economics. Prentice-Hall International, New Jersey.

Okuroğlu, M., Delibaş, L. 1986. Hayvan Barınaklarında Uygun Çevre Koşulları. Hayvancılık Sempozyumu, 05-08 Mayıs, Tokat.

Önal, A.R., Özder, M. 2008. Edirne İli Damızlık Sığır Yetiştiricileri Birliğine Üye İşletmelerin Yapısal Özellikleri. Tekirdağ Ziraat Fakültesi Dergisi, 5(2): 197-203.

Özen, N., Oluğ, H.H., 1997. Burdur Süt Sığırcılığının Sorunları ve Çözüm Önerileri. Trakya Bölgesi II. Hayvanc1lık Sempozyumu, 9-10 Ocak,Tekirdağ.

Özhan, M., Tüzemen, N., Yanar, M., 2009. Büyükbaş Hayvan Yetiştirme (Süt ve Et Sığırcılığı) (Düzeltilmiş 5. Baskı), Atatürk Üniversitesi Ziraat Fakültesi Yayınları Ders Notu Yayın No:134. 
Özyürek, S., Koçyiğit, R., Tüzemen, N. 2014. Erzincan İlinde Süt Sığırcılığı Yapan İşletmelerin Yapısal Özellikleri: Çayırlı İlçesi Örneği. Tekirdağ Ziraat Fakültesi Dergisi, 11(3):19-26.

Sheppard, S.C., Bittman, S., Swift, M.L. Beaulieu, M., Sheppard, M.I. 2011. Ecoregion and Farm Size Differences in Dairy Feed and Manure Nitrogen Management: A Survey. Canadian Journal of Animal Science, 91(3):459-473.

SPSS, 2004. SPSS for Windows Release 13.0. SPSS Inc., Chicago, IL.

Sümbüloğlu, K. ve Sümbüloğlu, V. 1998. Biyoistatistik. Hatipoğlu Yayınları, Ankara.

Şahin, O. 1994. Ayaş İlçesine Bağlı Köylerindeki Süt Sı ̆̆ırcılığının Yapısı. A.Ü. Fen Bil. Ens., Zootekni ABD, Yüksek Lisans Tezi.

Şeker, İ., Tasalı, H., Güler, H. 2012. Muş İlinde Sığır Yetiştiriciliği Yapılan İşletmelerin Yapısal Özellikleri. Fırat Üniversitesi Sağlık Bilimleri Veteriner Dergisi, 26(1): 9-16.

Tatar, A. M. 2007. Ankara ve Aksaray Damızlık Sığır Yetiştiricileri İl Birliklerine Üye Süt Sığırcılığg İşletmelerinin Yapısı ve Sorunları. A.Ü Fen Bil. Ens., Zootekni ABD, Doktora Tezi, 119 s.

Tilki, M., Sarı, M., Aydın, E., Işık, S., Aksoy, A.R. 2013. Kars İli Sığır İşletmelerinde Barınakların Mevcut Durumu ve Yetiştirici Talepleri: I. Mevcut Durum. Kafkas Üniversitesi Veteriner Fakültesi Dergisi, 19(1):109- 116.

Tugay, A., Bakır, G. 2006. Giresun Yöresindeki Özel Süt Sığırcılığı İşletmelerinin Irk Tercihleri ve Barınakların Yapısal Durumu. Atatürk Üniversitesi Ziraat Fakültesi Dergisi, 37 (1): 39-47.

TUİK, 2015. Türkiye İstatistik Kurumu. Hayvancılık istatistikleri. http://www.tuik.gov.tr, (Erişim tarihi: 10.11.2015).
Tutkun, M. 1999. Diyarbakır İli Merkez İlçeye Bağlı Köylerdeki Süt Sığırcılığının Yapısı. A.Ü Fen Bil. Enst. Zootekni ABD, Yüksek Lisans Tezi, $52 \mathrm{~s}$.

Uğurlu, N., Şahin, S. 2010. Kayseri İli Süt Sığırı Barınaklarının Yapısal Özellikleri. Selçuk Tarım ve Gida Bilimleri Dergisi, 24(2): 23-26.

Vasseur, E., Borderas, F., Cue, R.I., Lefebvre, D., Pellerin, D., Rushen, J., De Passillé, A.M. 2010. A Survey of Dairy Calf Management Practices in Canada that Affect Animal Welfare. Journal of Dairy Science, 93(3): 1307-1316.

Yamane, T. 2006. Temel Örnekleme Yöntemleri. Çeviri, Esin, A., Bakır, M.A., Aydın, C, Güzbüzsel, E. Literatür Yayınları: 53, İstanbul.

Yayar, R., Karkacıer, O. 1996. Tokat İli Pazar İlçesi Süt Sığırcılığı İşletmelerinin Ekonomik ve Teknik Özellikleri Üzerinde Bir Araştırma. Gazi Osman Paşa Üniversitesi Ziraat Fakültesi Dergisi, 13(1):269-288.

Yener, H., Atalar, B., Mungan M. 2013. Şanlıurfa İlindeki Sığırcılık İşletmelerinin Biyogüvenlik ve Hayvan Refahı Açısından Değerlendirilmesi. Harran Üniversitesi Veteriner Fakültesi Dergisi, 2(2): 87-93.

Yıldız, B. 2013. Çankırı İli Süt Sığırı Barınaklarının Yapısal Özellikleri ve Yeni Barınak Modellerinin Geliştirilmesi. S.Ü. Fen Bil. Ens., Tarımsal Yapılar ve Sulama A.B.D, Yüksek Lisans Tezi, 87 s.

Yildı, N., Bircan, H. 2006. Uygulamalı İstatistik. Nobel Yayın Dağıtım, Ankara.

Yıldız, Y. 1988. Çukurova Bölgesi Süt Sığırcılığı İşletmelerinde Mekanizasyon Uygulamaları. Tarımsal Mekanizasyon II. Ulusal Kongresi, 10-12 Ekim, Erzurum. 